reviews on cosmetic science, to name only a few. The countries represented on this occasion were : Belgium, Denmark, France, Germany, Great Britain, Norway, Sweden and the United States. Agreement was reached on a provisional constitution. The delegates are now returning to report to their national societies, and as soon as possible a second council meeting will be held to draw up a final constitution. A provisional secretariat has been established in London (2 Lovers Walk, London, N.3), but the final headquarters have yet to be agreed.

\section{Technical Assistance under the Baghdad Pact}

Is a written answer in the House of Commons on April 9, Mr. R. Allen, Joint Under-Secretary of State for Foreign Affairs, stated that at the sixth session of the Baghdad Pact Economic Committee in January 1959, the Government announced its intention to make available $£ 850,000$ per annum for technical assistance under the Baghdad Pact. This will be used for the supply of equipment and technical experts to Turkey, Iran and Pakistan and to provide training in the United Kingdom for nationals of those countries. In addition, the Government had contributed the equipment for the Nuclear Training Centre in Bagh. dad as well as some of the staff and running costs. Negotiations between the Pact Organization and the Iraqi authorities for the disposal of this equipment had not yet been completed.

\section{Scottish Technical Education Consultative Council}

Is a written answer in the House of Commons on May 1 the Secretary of State for Scotland, Mr. J. Mackay, announced that the new consultative body on vocational further education would be known as the Scottish Technical Education Consultative Coun cil; its terms of reference would be "to secure the widest possible measure of consultation on vocational further education in Scotland between employers, employees and those responsible for its provision, and to advise on, and generally to promote, the develop. ment of such education". Its chairman will be Mr. E. P. Hudson and its vice-chairman, Sir David Anderson.

\section{Government Chemist's Department}

IT was announced by Mr. J. E. S. Simon, Financial Secretary to the Treasury, in a written answer in the House of Commons on May 4, that the Government agrees with the Linstead Committee that the arrangement whereby the Chancellor of the Exehequer is responsible for the Government Chemist's Department is inappropriate in the present organization of Government scientific work. As from July l next, Ministerial responsibility for the Department will be transferred to the Lord President of the Council, and the Department will be placed in the charge of the Council for Scientific and Industrial Research.

\section{Building Research}

IN answer to a question in the House of Cornmons on May 5, the Minister of Works, Mr. H. Molson, said that the Government has for some time recognized. that there is room for improvement in the co-ordina tion of building research, and it has therefore been decided to place all such research under the Department of Scientific and Industrial Research. $\mathrm{He}$ is not therefore re-appointing his Advisory Council on Building Research and Development, and in its place there would be a Standing Conferonce on Building Research under the ægis of the Lord President of the
Couneil. The dissemination of technical information will remain his responsibility and he is discussing with the industry the many problems involved in providing rapid facilities for this purpose.

\section{Journal of Biochemical and Microbiological Technology and Engineering}

IT is generally recognized that chemistry imposes certain special conditions on the technologists and engineers who work in chemical industry. Biology, too, possesses its own characteristics which must be understood by people who are proposing to use living cells for practical purposes in biological industry. It is with this in mind that three editors, two from the University of London and one from Columbia University, New York, assisted by an advisory board of sixteen drawn from Australia, India, Ireland, Italy, The Netherlands, Sweden, Switzerland, the United Kingdom and the United States, have brought out this new journal. The first number (Journal of Biochemical and Microbiological Technology and Engineering, 1, No. 1 ; February 1959. Pp. 127. Published quarterly : subscription, covering one volume annually, $£ 515 s$, including postage; outside the United Kingdom, 15.50 dollars. New York and London: Interscience Publishers, Inc., 1959) contains nine papers which nicely illustrate the kind of topies with which the publication is intended to deal. For example, an American contribution describes the separation of proteins by means of foam; N. W. Pirie reviews the principles employed in different types of presses, filters and centrifuges by which fluids may be separated from fibrous pulps on a large scale; and the British Flour-Millers Research Association presents a paper on the use of air classification as a means of varying the protein content of flour. Besides these, there are reports on equipment for the culture of algae and of micro-organisms of diverse kinds for various purposes, on the destruction of moulds by irradiation, on the evaluation of microbiological nutrients and on means for the removal of algae from drinking water. Pure and applied science must always be inextricably mixed. Neither physicists nor chemists could achievo their modern triumphs without their technologies. The present journal can usefully inform biologists about theirs.

\section{Locusts and Atmospheric Turbulence}

IN a paper entitled "Flying Locusts and Atmospheric Turbulence" (Quart. J. Roy. Meteor. Soc., 84, 334 ; 1958), Dr. R. C. Rainey describes the relation between the structures of the lower atmosphere and of locust swarms over eastern Africa. It is found that, in a convectively unstable atmosphere of very high lapse-rate of temperature, the locusts are carried high into the air in the convection currents. They are spread out over a considerable depth rather like a cumulus cloud so that there is a nearly clear space for some distance above the ground, while the top of the swarm approaches the limit of the region of high lapse-rate at 1-2 km. above the surface. During stable (isothermal) conditions, on the other hand, the swarm forms a thin layer at a height of a few tens of metres above the ground. In such conditions, locusts frequently settle on the ground, and take off again as the swarm progresses. The locust swarm is not, however, merely carried along by the air and dispersed by turbulence as though it were a cloud of dust particles. Evidence is presented to show that, even in highly convective aix, the swarms persist as swarms. The 